\title{
In Memoriam: John Jeffries
}

"My father, John Jeffries, was a man who never really realised his own worth or what he'd achieved. I think everyone here probably understands better than he did how excellent a person he truly was" Helen Jeffries' Eulogy at John's funeral.

How true these words are. John was a highly valued and hugely influential member of our profession for a number of years in the late 1970's and early 1980's but then slipped away from the limelight and is probably little known among the present membership.

John was born in 1948. He was a gifted child who succeeded academically, even though he came from an ordinary background. Both his parents were workers at Cadbury's Chocolate factory. He studied at Leeds University and he worked for some years at the University of Kent, specialising in law librarianship and running a European Documentation Centre. He was a founder member and key personality behind the establishment of the Association of EDC Librarians in 1981, which later became the European Information Association, which sadly ceased existence at the end of 2012. In 1978 he published a book entitled $A$ Guide to the Official Publications of the European Communities.

He later took a job in Leicester at the National Youth Bureau and then went on to work for Wragge \& Co in Birmingham. Subsequently he worked alongside me as a director at Legal Information Resources. His final professional work was as a legal indexer working from home for, amongst others, the IBA', Oxford University Press and Cambridge University Press. During this time he became an active member of the Society of Indexers.

Alongside his academic career John maintained a rich intellectual life, with interests ranging from information technology, as the web was first coming into being, through naval history to literature, art and architecture. $\mathrm{He}$ also became involved with preserved railways, both practically and intellectually, obtaining his $\mathrm{PhD}$ in the 1980s on the management of the Kent and East Sussex Railway Company. Later in life he took pleasure in travelling, particularly to Scotland. Recently he had found faith and was confirmed into the Church of England.

John was a very important figure within BIALL. He became involved in the Association whilst at Kent. He was Chairman of the Standing Committee on Training from 1978-1980; Treasurer from 1980-1982 and Chairman from 1982-1986. In those days terms of office were not time-limited and he put a huge amount of work into everything he did for us ${ }^{2}$. He was later made a Life Member in recognition of his services to the Association.

It was a pleasure to work with him. He had a great sense of humour but was also tough; for example, he got changes to the constitution through the AGM without opposition. He was renowned for very brief AGMs, sometimes as short as 20 minutes and he maintained excellent discipline through all the meetings he conducted as Chair of the Association. He also did a great deal to build up the relationship with AALL, visiting the US with a delegation of law librarians in 1985 to further this work ${ }^{3}$.

He will be sadly missed by those who worked with him and by his family and friends and our sympathies are extended to his daughter, Helen.

Christine Miskin

\section{Footnotes}

I The last edition of the Journal of Energy and Natural Resources Law contained the following paragraph: "The IBA editorial team and I dedicate this final issue of JERL volume 30 to Dr John Jeffries, the publication's longstanding indexer who sadly passed away November 2012. Always committed to the journal, John was a pleasure to work with and will be very fondly remembered". Don C Smith Editor, Journal of Energy \& Natural Resources Law University of Denver, Sturm College of Law, US

${ }^{2}$ For an appreciation of John's work, written by Wallace Breem, see: John Jeffries - retiring Chairman. 1986 Law Librarian I7(2) p.74

${ }^{3}$ For a report of the visit see: Howes, Robert. American Association of Law Libraries. 1985 Law Librarian I6(3) p. 121
} 